\title{
Developments in Analytical Methods for Detection of Pesticides in Environmental Samples
}

\author{
Rama Bhadekar*, Swanandi Pote, Vidya Tale, Bipinraj Nirichan \\ Department of Microbial Biotechnology, Rajiv Gandhi Institute of Information Technology \& Biotechnology, \\ Bharati Vidyapeeth Deemed University, Pune, India \\ E-mail:"neeta.bhadekar@gmail.com \\ Received November 19, 2011; revised December 21, 2011; accepted December 28, 2011
}

\begin{abstract}
The present review gives a survey of all the published methods along with their advantages and limitations. Traditional methods like thin layer chromatography, gas chromatography, liquid chromatography etc are still in use for this purpose. But some recent bio-analytical methods such as immunosensors, cell based sensors etc. have also gained equal importance. This article also overviews various electro-analytical methods and their applications as detection devices when combined with FIA and biosensors. Lastly nanoparticle based biosensors have also been discussed. The review concludes with futuristic approach to reduce the risks caused by pesticides. This scrutiny should provide concise evaluation of different techniques employed for pesticide detection in environmental samples.
\end{abstract}

Keywords: Biosensors, Chromatography, Detection, Flow Injection Analysis, Nano Particles, Pesticides, Pollutants

\section{Introduction}

People have contradictory ideas about the meaning of pesticides. The dictionary defines pesticide as a substance for destroying harmful insects. The scientists are of the opinion that pesticides are chemical or biological substances that are designed to kill or retard the growth of pests interfering with the growth of crops, shrubs, trees, timber and other vegetation desired by humans. The term pesticide includes substances intended for use as plant growth regulators, defoliants, desiccants or agents for thinning fruit or preventing the premature fall of fruit. The substances applied to crops either before or after harvest to protect the commodity from deterioration during storage and transport also come under the category of pesticides [1].

Pesticides are broadly classified into two groups viz A) chemical pesticides and B) biopesticides. A) Chemical pesticides are conventionally synthetic materials that directly kill or inactivate the pest. They are classified according to the type of organisms they act against as for example 1) insecticides, 2) herbicides, 3) fungicides, 4) rodenticide, 5) nematicides [2]. Insecticides include organophosphates (TEPP, parathion. trimesters of phosphates and phosphoric acids), carbamates (aldicarb), or- ganochlorines (dichlorodiphenyltrichloroethane, chlordane, aldrin, dielrin, lindane, endrin) and botanical insecticides (nicotine, rotenoids, pyrethrum). Herbicides are used to destroy other weeds that interfere with production of the desired crop. Based on their structure they are grouped into chlorophenoxy compounds (e.g.: 2,4-D, 2, 4,5-T), dinotrophenols like 2-methyl-4,6-dinitrophenol (DNOC), bipyridyl compounds like paraquot, carbamate herbicides, substituted urea, triazines and amide herbicides like alanine derivatives. Fungicides include a number of structurally different chemicals like cap tan, folpet, pentachlorophenolziram, nambam etc. Fungicides containing mercury are known to cause nerve disorders [2]. Rhodenticides are designed to kill rodents, mice, squirrels, gophers and other small animals. They vary from highly toxic one with the ability to kill an organism with one-time dose or less toxic ones requiring repeated ingestion over a period of time. Nematicides act against nematodes like Meloidogyne incognita, Criconemella xenoplax etc.

B) Biopesticides are pesticides derived from natural sources like animals, plants, bacteria, and certain minerals. For example, canola oil and baking soda have pesticidal applications and are considered biopesticides. Biopesticides fall into three major classes: 
1) Microbial pesticides consist of microorganisms like bacteria, fungi, viruses or protozoa as the active ingredients. They can control many different kinds of pests, although each with separate active ingredient that is relatively specific for its target pest(s). 2) Plant-Incorporated-Protectants (PIPs) are pesticidal substances that are produced by genetically modified plants for example: introduction of $\mathrm{Bt}$ toxin gene in the cotton plants. 3) Biochemical pesticides are naturally occurring substances that control pests by non-toxic mechanisms (for e.g. insect sex pheromones that interfere with mating as well as various scented plant extracts). Biopesticides are environmentally safe and non toxic to plants and animals. However, their use is limited due to 1) less social awareness, 2) comparatively lower crop yields, 3) need for frequent applications, 4) less worked research area.

On the contrary, application of chemical pesticides has proved to be economically beneficial and hence their use has increased globally especially after the advent of "Green Revolution". The productivity of crop has been increased by use of suitable pesticide. They protect the crop from disease causing organisms, from plant pathogens and also from vector borne diseases. Another important advantage is reduction in cost of labor.

Even though pesticides play significant role in agriculture they are the most important environmental pollutants. This is due to their wide spread presence in water, soil, atmosphere and agricultural products. Currently it poses major threat not only to living organisms but also to environment specially ground and surface water. Synthetic pesticides affect the growth of plants. Chemical compounds in the pesticides are not biodegradable. This causes their sedimentation near plant roots making the supply of essential NPK inefficient. This inefficiency hinders growth of crops and their resistance to other harmful microbes. Pesticides percolate into the soil and get mixed with ground water. This causes draining of pesticides into the nearby stream or lake. This in turn adversely disturbs the aquatic eco system. Soil is another important component for plant growth. Pesticides hamper the fertility of soil by inhibiting the storage of nitrogen and other essentials in soil. Light and toxic compounds are suspended in air by pesticide spray. This causes air borne diseases and nasal infections. Besides all the environmental hazards; pesticides pose serious risk to mankind. Health hazards caused by some of the pesticides are summarized in Table 1. Different pesticides have different acceptable residual levels and these are set up by World Health Organization (WHO), European Community (EU), FAO (Food and Agricultural Organization) of UN, US environmental protection agency (EPA) and the US National Institute for Occupational Safety and Health (NIOSH) [3-5]. The Toxicity of pesticides, made it essential to have accurate and reliable methods of monitoring their levels for safety purposes. Earlier techniques used for pesticide detection were chromatographic methods like Gas Chromatography (GC), High Performance Liquid Chromatography (HPLC) along with Mass Spectrometry (MS) etc. They were sensitive and reliable. However, they had limitations like 1) complex procedure, 2) time consuming sample treatments, 3) need of highly trained technicians, 4) inability to perform on site detection etc. To improve these methods newer techniques are being developed. The new techniques use more sensitive devices like chromatographic techniques with various detection methods, electro analytical techniques, chemical and biosensors, spectroscopic techniques and flow injection analysis (FIA). Sometimes a combination of one or more methods proved successful in detecting a particular class of pesticide. This article presents an all embracing survey of the classical methods along with update knowledge of recent advances in the techniques.

\section{Spectrophotometry}

This was a widely used method for the detection of pesticide residues from environmental samples. Spectro-

Table 1. Harmful effects of pesticides on humans.

\begin{tabular}{|c|c|c|}
\hline Type of pesticide & Effects observed & Ref. \\
\hline Organophosphates & $\begin{array}{l}\text { Adversely affects nerve functioning, direct exposure can cause eye problems like blurring of } \\
\text { vision, reddening, retardation in fetal growth etc. }\end{array}$ & {$[6,7]$} \\
\hline Chlorides & $\begin{array}{l}\text { Disruption of dopamine transport in the brain, increased risk of lung and pancreatic cancer, } \\
\text { neutrophil inflammation etc. }\end{array}$ & {$[8]$} \\
\hline Methyl Bromide & Increase in serum albumin level & {$[9]$} \\
\hline Fungicides like atrazines, amides, etc. & $\begin{array}{l}\text { Irritation of skin and eyes, slowing of heart beats, weakness of muscles, central nervous system } \\
\text { disorders etc. }\end{array}$ & [11] \\
\hline $\begin{array}{l}\text { Rhodenticides like Strychnine Sodium } \\
\text { monofluoroacetate Thallium, etc. }\end{array}$ & $\begin{array}{l}\text { Complete loss of hair, paresthesias, nausea, vomiting and abdominal pain, pulmonary oedema } \\
\text { bronchopneumonia, diaphoresis, blurred vision and severe symmetric extensor muscle spasms }\end{array}$ & {$[12]$} \\
\hline
\end{tabular}


photometry measures the amount of light absorbed by the analyte solution and this amount of light is directly proportional to the quantity of the analyte. The technique is based on two properties of light: 1) particle nature of light and 2) wave nature of light. The former gives rise to photoelectric effect and the latter results in formation of visible spectrum of light. Normally white or UV light is used as a source of light. The beam of light splits into its component wavelengths after passing through the prism. Light of different wavelengths is absorbed by different analyte solutions to different extent depending on analyte concentration. The analyte particles absorb photons and then the unabsorbed photons are converted into electrical signal by the phototube. The detection unit then records the difference in the intensity of light. The difference in the intensities of source beam and the beam coming out of the analyte determines the concentration of the analyte. The components of a spectrophotometer are 1) source of light, 2) cell containing analyte solution, 3) phototube, and 4) detection unit. Use of this technique for detection of atrazine and dicamba herbicides from water samples was described by Hernández et al., (2005). The authors reported detection limits (LOD) of $0.1 \mu \mathrm{g} / \mathrm{ml}$ for atrazine and $0.2 \mu \mathrm{g} / \mathrm{ml}$ for dicamba [13]. Moreover spectrophotometric detection methods were also found suitable for detection of organopesticides such as malathion, phorate and dimethoate from food samples. The procedure was based on oxidation of organophosphoours pesticides with slight excess of N-bromosuccinimide. The unconsumed N-bromosuccinimide was then reacted with rhodamine B which was followed by spectrophotometric estimation of decrease in color at $550 \mathrm{~nm}$. The sensitivity of the methods was up to $\mu \mathrm{g} / \mathrm{g}$ [14].

Even with limited success in these methods, some drawbacks were evident. They were 1) extensive sample preparation, 2) relatively slow and 3) could not be used for real time estimation. Hence these days spectrophotometric methods are used only for detection of limited number of pesticides. Sometimes they are coupled with other systems as terminal detection devices to detect pesticides.

\section{Electroanalytical Techniques}

Electroanalytical techniques have gained importance for analysis of environmental samples. Their main advantages are simplicity in operation, sensitivity, selectivity, portability and so on. Commonly used electroanalytical techniques are: potentiometry, conductometry, voltametry, amperometry etc [15]. The basic principles of these techniques are discussed below.

\subsection{Potentiometry}

Potentiometry measures the potential of electrochemical cells. A potentiometric cell is composed of i) reference electrode ii) salt bridge iii) analyte solution and iv) indicator electrode. The commonly used reference electrodes are hydrogen electrodes, calomel electrodes or silver/ silver chloride electrodes. The indicator electrodes can be either metallic or ion selective. The salt bridge acts as a barrier between the standard electrode and the analyte solution. Potentiometric methods are governed by Nernst equation. The potential (E) is calculated as (1) $[16,17]$.

$$
\mathrm{E}(\text { cell })=\mathrm{E}(\text { indicator })-\mathrm{E}(\text { reference })
$$

\subsection{Conductometry}

It is based on the property of electrolyte solutions to dissociate into ions. It measures the change in electrical resistance of a solution. A conductometric cell consists of 1) two electrodes: Anode (positively charged) and cathode (negatively charged) 2) an electrolyte solution and 3) battery (current reading detection unit). The number of ions determines the amount of current generated which indicates the concentration of electrolytes. The electrolytic properties of a conductor are described by Ohm's law (2) and the conductance is given by (3) $[18,19]$.

$$
\mathrm{V}=\mathrm{IR}
$$

Equation (2) is V (voltage), I (current), R (electrical resistance)

$$
\mathrm{G}=1 / \mathrm{R}
$$

Equation (3) is $\mathrm{G}$ (conductance).

\subsection{Voltametry}

It measures the change in the current-potential characteristics of an electrochemical cell. This change is directly proportional to the concentration of the analyte. The current-potential relationship is dependent on the mass transfer rate. It is the rate at which the electroactive species generated due to oxidation reduction reactions reach the electrode. This mass transfer can be due 1) ionic migration (formed due electrochemical gradient) 2) diffusion under a chemical potential difference or 3) bulk transfer. In voltametry the potential applied is usually varied as a function of time. Based on this voltametry is grouped into A) linear voltametry and B) cyclic Voltametry. In former the potential applied to the electrochemical cell is gradually increased. In latter, the potential is varied between a fixed lower and upper value [20, 21]. 


\section{Amperometry}

Amperometry can be considered as a sub-class of voltametry since both the procedures depend on the same principal. The only difference in voltametry and amperometry is that in amperometry the potential applied across the cell is constant. It measures the current generated due to the oxidation-reduction reactions taking place in the analyte solutions.

The electroanalytical techniques are described in detail by Bard et al. [22]. Many variations in these techniques have been reported in literature. For instance amperometry and potentiometry are coupled together for quantifycation of analytes. One or more of these techniques are combined with other methods like chromatography, biosensors, flow injection analysis etc. for pesticide analysis from environmental samples. Applications of these techniques are discussed below.

\section{Chromatographic Techniques}

Chromatographic techniques are among the first few techniques that were put to use for pesticide detection. As technology developed various modifications have been made in basic chromatography. However all forms of chromatography utilize the property of the analyte to distribute itself between two immiscible phases ( $\mathrm{X}$ and $Y)$. This co-efficient of distribution remains constant at a particular temperature and is given by (4)

$$
a / b=\text { Coefficient of distribution }
$$

Equation (4) is a = concentration of analyte in $\mathrm{X}, \mathrm{b}=$ concentration of analyte in $b$.

Every chromatographic system consists of two phases viz. stationary phase which is immobilized (solid, gel, liquid or mixture of solid and liquid) and a mobile phase which is passed over the stationary phase (gas, liquid). While performing the method the analytes continuously move between the two phases. They get separated from each other because of the difference in their distribution co-efficient. A typical chromatographic unit is made of stationary phase, mobile phase, a column, injector system, a detector, chart recorder and fraction collector. The performance of the system depends mainly on three factors; 1) Retention time (T) (5) 2) retention factor which is the time taken by the analyte bound to the stationary phase to elute from the column relative to the time taken by the free analyte and 3) column height and resolution.

$$
\mathrm{T}=\mathrm{Tx}-\mathrm{Ty}
$$

Equation (5) is Tx: Time for which the stationary phase retains the analyte.
Ty: Time taken by the analyte to bind to the stationary phase.

Chromatographic analysis requires sample preparation. This makes the technique more time consuming. The main steps of sample preparation are: 1) solvent extraction (for example by acetone or acetonitrile) or solid phase extraction, 2) column switching (beneficial for HPLC: here the analyte is adsorbed on a suitable adsorbtant. The impurities are washed and then the analyte is eluted with an appropriate organic solvent.), 3) supercritical fluid extraction (gases for example, liquid carbon dioxide is used for solvent extraction) and 4) sample derivatisation (involves covering of functional groups in the analyte, adversely affecting the chromatographic detection). After a pesticide has been extracted and isolated from the sample, it is further separated from other coextractives. It makes use of gas chromatography or liquid chromatography or, less frequently thin layer chromatography [23].

\subsection{Thin Layer Chromatography (TLC)}

In TLC the stationary phase is bound to a glass or a metal plate. The sample is spot inoculated or applied as a thin band near the end of the plate. The mobile phase flows over the stationary phase by capillary action. Separation of analytes takes place by adsorption or partition or ion exchange or molecular exclusion depending on the type of stationary phase. The movement of the analyte depends on the retardation factor (6)

$$
\text { Retardation factor }=\mathrm{x} / \mathrm{y}
$$

Equation (6) is $\mathrm{x}=$ distance traveled by analyte from start point, $\mathrm{y}=$ distance traveled by mobile phase from start point.

TLC is usually followed by detection of compounds by i) examining the plate under UV, ii) spraying the plate with reagent which reacts with the compound to form coloured products, iii) use of fluorescent dye iv) by radio labeling the analytes and observing them by radiography. The separated compounds can be quantified with a precision densitometer. A number of modifications in TLC technique are used to detect pesticides. They are listed below.

\subsubsection{TLC Bioassay}

This technique described by N. K. B. Ardikaran et al. (2009) uses a TLC plate sprayed with spores of $\mathrm{Ca}$ dosporium cladosporioides for detection of fungicides. Here the presence of pesticide is confirmed by absence of fungal growth around the sample spot [24]. 


\subsubsection{High Performance Thin Layer Chromatography (HPTLC)}

HPTLC is an advanced form of TLC. The main advancement is introduction of automation for all the steps involved in HPTLC. Due to automation it is possible to attain precision in the sample size and also the position at which the sample is applied on the TLC plate. This advancement rules out the possibility of variation in results due to human error. HPTLC can also be effectively used for two dimensional TLC. High performance thin layer chromatography (HPTLC) with use of automated multiple developments (AMD) makes use of gradient to separate pesticide compounds. The gradient is formed by running a single or multiple mobile phases over the TLC plate. This method has been used for screening of a variety of pesticides including organophosphates, urea, triazines etc. with LOD ng/l [25].

HPTLC with diode array scanning was used to detect atrazine, clofentezine, chlorfenvinphos, hexaflumuron, terbuthylazine, lenacyl, neburon, bitertanol, and metamitron from water samples. Here samples were extracted by solid phase extraction on octadecyl silane. Dichloromethane was used as an eluent and LOD was $0.04-0.23$ $\mathrm{ng} / \mathrm{spot}[26]$.

HPTLC combined with different detectors like conductometry [27], multi enzyme assay [28] have been used for pesticide analysis. Advances in TLC are reviewed by Sherma [29].

\subsection{Gas Chromatography}

Gas Chromatography (GC) is based on difference in partition coefficients between a liquid stationary phase (silicone grease or wax) and a gaseous mobile phase (inert carrier gas like nitrogen). This method is applicable only for volatile compounds. The partition coefficients are inversely proportional to the rate of volatilization of the compound. Gas Chromatography (GC) is routinely used for qualitative and quantitative analysis of pesticides. The main components of a GC unit are represented in Figure 1. The detection unit is an important part of a GC unit from the analytical point of view. The same unit can be employed for detection of variety of compounds by varying the type of detector. The different types of detectors are Flame Ionization Detector (FID), Nitrogen Phosphorous Detector (NPD), Electron Capture Detector (ECD), Flame Photometric Detector (FPD), Pulse Photometric Detector (PPD), infrared detector, Mass Spectrometer (MS) etc. The use of these detectors for pesticide detection is summarized in Table 2.

\subsection{Liquid Chromatography (LC)}

Simple liquid chromatography consists of a column with a narrow bottom containing the stationary phase. The column is a made of glass and its length and diameter depend on the compound to be separated. The optimum working of LC depends on the matrix on which the stationary phase is immobilized. The matrix used should have high mechanical and chemical stability to ensure optimum flow rate. The matrix is made up of inert materials like agarose, cellulose, dextran, polyacrylamide, silica, polysterene etc. The stationary phase is always in equilibrium with a solvent. The sample is loaded onto the top of the column by i) direct application, ii) using sucrose gradient or iii) with the help of a peristaltic pump along with solvent. The different components in the sample mixture pass through the column at different rates. This is due to differences in their partitioning coefficients between the mobile liquid phase and the station-

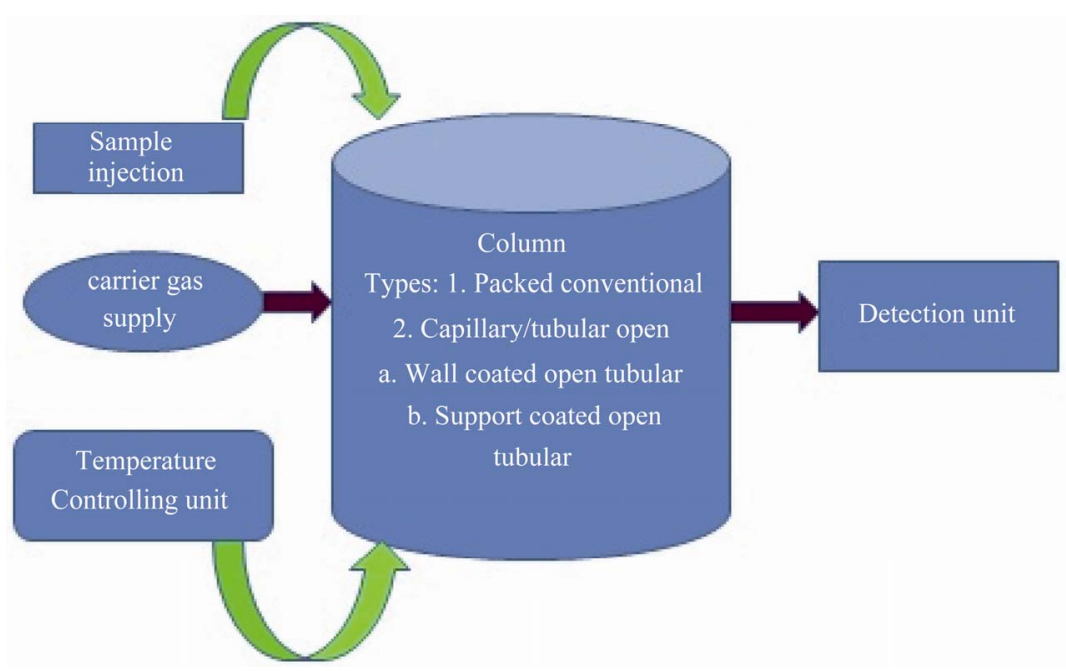

Figure 1. Components of gas chromatography unit. 
Table 2. Gas chromatography with various types of detectors.

\begin{tabular}{|c|c|c|c|c|}
\hline System & Sample Type & Pesticide Detected & Detection Range & Ref. \\
\hline GC-PFPD & Food & Acephate, Aldrin, Dicofol, Endrin, Captan etc. & $0.003-0.2 \mathrm{ppm}$ & {$[31]$} \\
\hline GC-MS with large volume injection & Food & Trifluralin, Dicholoron etc. & $100 \mathrm{ng} / \mathrm{l}$ & {$[32]$} \\
\hline GC with microwave emission detector & Food & Parathion & $0.5 \mathrm{ppb}$ & {$[33]$} \\
\hline GC with PFPD & Food & Organophosphates & $\mathrm{ppb}$ & {$[34]$} \\
\hline GC-ECD/FID and NPD & Food, water, soil & Nitogen and phosphorous containing pesticides & $380 \mathrm{mg} / 1$ & {$[35]$} \\
\hline Capillary GC & Water & Organochlorines & $6-300 \mu \mathrm{g} / 1$ & [36] \\
\hline GC-MS & Meconium & Cypermethrin, malathion,cyfluthin etc. & $0.01-4-15 \mu \mathrm{g} / \mathrm{g}$ & [37] \\
\hline
\end{tabular}

ary phase. The compounds are separated by collecting aliquots of the column eluent at different time intervals [23]. This chromatography is widely used in combination with MS for pesticide quantification [30]. Methods based on separation with MS detection are found to be extremely useful as compared to GC-MS [38]. This technique has been successfully been applied for detection of organophosphates, organochlorines etc. However certain modifications in the LC are essential. This is because many a time pesticides cannot be detected in one run due to interference of groups present in the pesticides. In order to overcome these problems dual LC-MS systems have been developed. In such a unit two types of experimental conditions can be simultaneously applied for effective separation.

High Performance Liquid Chromatography (HPLC) This type of chromatography has a better edge over other types of chromatography. The reason behind is the materials used for making the column can withstand high pressure and flow rates. Here usually the columns are long $(3-50 \mathrm{~cm})$ in length and $1-4 \mathrm{~mm}$ in diameter. The HPLC unit consists of 1) stationary phase which is either in microporous, pellicular or bonded form, 2) mobile phase, 3) pumps for delivering the eluent and 4) detectors. The detectors used are: Variable wavelength length detectors, Scanning wavelength detectors fluorescence detectors, electrochemical detectors, mass spectrometer, NMR spectrometer, refractive index detector and evaporative light scattering detectors and so on. Vodeb et al. (2006) have used HPLC with a diode array detector to quantify $\beta$-cyfluthrin with reverse phase and normal phase types of column [39].HPLC combined with supercritical fluid extraction has been used to detect multiple pesticide residues from food samples in the method described by Kaihara et al. (2000). The authors have reported LOD of $0.005-0.1 \mathrm{ppm}$ [40]. Application of re- verse phase HPLC with acetonirile gradient and UV dectector for detection of dalazion, malathion and sumuthion is illustrated by Islam et al. (2009) [41]. HPLC with $\mathrm{CD}$ detector has also been used for detection of chiral pesticides.

\section{Electrochemical Sensors and Biosensors}

Biosensors have been described as analytical machines coupled with bio recognition elements with various detection techniques. The biological components include enzymes, antibodies, microorganisms or DNA. The immobilized biocatalyst incorporated into the sensor allows continuous utilization of substrate. These methods have been reviewed extensively by Theveno et al. (2001) [42]. With the help of biosensors, on site analysis can be performed to understand the extent of pollution almost immediately [43-46]. The advantages of using biosensors are: 1) disposable, selective, reliable and economical 2) they can be produced in large quantities and can be miniaturized for efficient use for onsite detection, 3) require less sample size and 4) easy to operate even by non skilled personnel [47-50]. In spite of their clear advantages, they have certain limitations. They have low response stability low mechanical stability, high diffusion resistance of substrate/bio component assembly; interfering signals form other compounds in real samples etc [51]. However, these drawbacks can be minimized by proper designing of the biosensor. For convenient use, biosensors are usually coupled with an electrochemical sensor. The sensors are potentiometer, amperometer, voltameter, conductimeter etc. This coupling gives the data in readable form. A number of electrochemical sensors are available commercially. Certain characters like selectivity, response time, and linear range, limit of detection, reproducibility, stability and lifetime of biosensors are compared with standard IUPAC protocols for their per- 
formance evaluation [52-54]. Different types of biosensors coupled with electrochemical devices are briefly described below.

\subsection{Cell Based Biosensors}

They make use of living microorganisms such as algae, bacteria, yeast and fungi as bio-catalytic elements. Their main advantage is that they are easy to develop and there is no need for isolating sub-cellular components like enzymes, antibodies, antigens etc to detect pesticides. Various examples reported in literature are summarized in Table 3.

\subsection{Enzyme Based Biosensors}

These biosensors measure the activity of the enzyme or enzymes used in the system. The activity of the enzyme depends on the various factors. They are amount of substrate, time of incubation, presence of inhibitors, reactions conditions like $\mathrm{pH}$, temperature etc. To make the system more cost effective, enzymes are immobilized using various methods [55-58]. Mostly such biosensors are based either on enzyme activity or enzyme inhibiton. Example of former is organophosphorus hydrolase (OPH) with broad substrate specificity. Biosensors of second type often make use of Choline estarese (CE), acid phosphatase, tyrosinase, ascorbate oxidase, acetolactate synthase, aldehyde dehydrogenase etc. In such systems, acetylcholine esterase (ACE) immobilized on activated silica gel is most commonly used. The method is based on enzyme inhibition since carbamate and organophosphte pesticides inhibit the activity of ACE. ACE primarily hydrolyses neurotransmitters producing choline and acetic acid. (7) Carbamate (C) pesticides reversibly inhibit this enzyme (8) whereas organophosphates (ORP) inhibit it irreversibly (9).

$$
\begin{gathered}
\text { ACE }+\mathrm{H}_{2} \mathrm{O} \rightarrow \text { Choline }+ \text { Acetic acid } \\
\mathrm{ACE}+\mathrm{C} \leftrightarrow \text { ACE-C } \\
\mathrm{ACE}+\mathrm{ORP} \leftrightarrow \text { ACE-ORP }
\end{gathered}
$$

The production of acetic acid results in change of $\mathrm{pH}$ of the system. This can be easily monitored using spectrophotometer [59] fluorescence indicator [60], potentiometer [61] or direct measurement by $\mathrm{pH}$ meter using glass electrode or change in conductance of medium. Research on enzyme based methods for detection is extensively discussed in review by Van Dyk et al. [62]. Examples of both the types enzyme based sensors are summarized in Table 4.

\subsection{Immunosensors}

These biosensors are based on the property of specific binding of two immunological molecules viz. antigen and antibodies. They are characterized by sensitivity, rapidity, specificity, low cost and ability to analyse large number of samples. Here pesticide specific antigen-antibody reactions are employed for their detection. For quantification purposes the antigen-antibody reactions are coupled with enzyme labels. Immunosensors are of two types: i) labeled type and ii) label free type. The first type makes use of different enzymes like glucose oxidase, horse raddish peroxidase, alkaline phosphatse etc. Two different methods viz: sandwhich assay and competitive assay are used with labeled type. Similarly labeled free types of sensors are grouped into direct and indirect types. The applications of immunoassay as pesticide detection method have been reviewed in many papers [6365]. Commercial immunoassay kits are also available in the market. In immunosensors, sensing element can be either an antibody $(\mathrm{Ab})$ or an antigen $(\mathrm{Ag})$ which is immobilized on a transducer. If $\mathrm{Ab}$ is immobilized, the binding of analyte can be measured directly. If $\mathrm{Ag}$ is immobilized, the detection is based on the competition between immobilized Ag, the analyte, and a fixed amount of $\mathrm{Ab}$. Mainly four types of immunosensors are reported viz piezoelectric, optical, electrochemical or thermometric. Piezoelectric immunosensors: are more common due to label free detection of atrazine, parathion etc [84-86]. A piezoelectric crystal can be coated with an $\mathrm{Ag}$ or $\mathrm{Ab}$ and the change in the mass by the binding of the analyte can be correlated to the concentration of the analyte [87]. Optical immunosensors: Main optical immunosensros

Table 3. Use of whole cells for pesticide detection.

\begin{tabular}{ccc}
\hline Type of Cell & Electrochemical sensor & Pesticide Detected \\
\hline $\begin{array}{c}\text { Escherichia coli } \\
\text { Pseudomonas putida }\end{array}$ & Potentiometric & Paraoxon, Parathion, Methylparathion, Diazinon \\
Moraxella sp & Pmperometric & Paraoxon, Parathion, Methyl parathion $\quad$ Triazines, Parathion, Carbamates, Organophosphates $\quad$ O66] \\
Chlorella vulgaris & Conductometric & Organophosphates \\
\hline
\end{tabular}


Table 4. Biosensors based on enzymes.

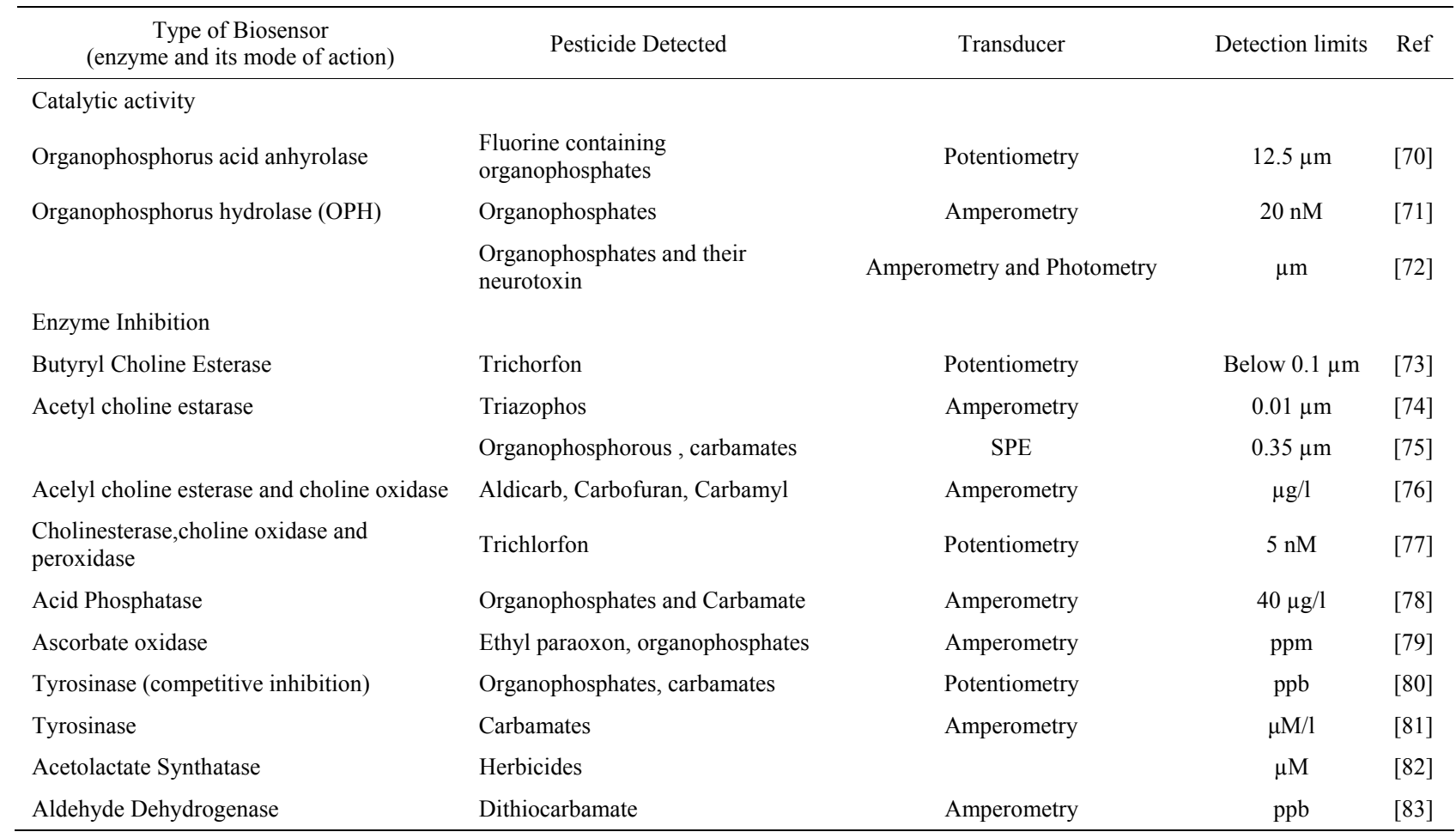

$\mathrm{SPE}=$ Screen Printed Electrode.

developed are based on Surface Plamon Resonance (SPR) device. In another type of optical immunosensor, the $\mathrm{Ab}$ is coated on the metal sheet causes a minute change in the refractive index when bound with the analyte and this change can be detected by the SPR device. Another optical immunosensor is based on total internal reflection fluorescence (TIRF). These biosensors are used to detect terbutryn, atrazine, parathion, polychlorophenol etc [88].

\subsection{Nucleic Acid Based Biosensors}

These biosensors utilize the oxidation property of the nucleic acid base guanine [89]. They are based on interaction of DNA molecules with pesticides. Such reactions can be detected by monitoring the change in redox potential. For this purpose electrochemical sensors like voltametry and potentiometry are used (here DNA is immobilized on the electrodes). Sometimes the change in electroactive analytes that are intercalated on DNA layer is also monitored. Nucleic acid biosensors have been extensively reviewed in a review published by Fang et al. [90].

\subsection{Use of Nano Particles in Biosensors}

Recent developments in enzyme based biosensors include use of gold nano particles to increase accuracy.
Moreover these sensors have multiplexing facility which allows detection of trace amounts of pesticides. Because pesticides are present in trace amounts pre concentration and extraction steps are essential prior to detection. Developments in nano materials particularly applications of carbon nano tubes as sorbant in solid phase micro extraction techniques has been elaborately discussed by Pyrzynska [91]. These particles increase the adsorption and stability of ACE on planar gold electrode surface [92]. Nanoparticle layer also improves the sensitivity and detection limit of the device. Slight change in the environment can disturb the charge based distribution of such sensors affecting the detection of pesticides. However, new studies and developments in surface chemistry and material physics along with proteomics can overcome this hurdle. It delivers fine and accurate measurement of any environmental pollutant.

Alvarez et al. [93] has shown the use of nanomechanical biosensors for the real time detection of organochlorine pesticides like DDT. In this method cantilevers are coated with DDT5 hapten molecules over a self assembled monolayer of alkanethiol with gold nanopartilce. Assay is performed by mixing the samples containing a fixed concentration of DDT monoclonal antibody with DDT solutions at different concentrations. After the incubation only the free antibody couples with the bioreceptor on the cantilever. The difference in the 
deflection occurs due to change in the surface stress of the cantilever. It can be detected by a laser beam sensitive photodetector.

Gan et al. [94] have developed a highly sensitive disposable enzyme biosensor based on composite magnetic nanoperticles modified screen printed carbon electrode (SPCE). Organophosphates are detected by the inhibition of the acetyl cholinesterase catalyzed hydrolysis of acetylthiocholine. In this method the biosensor was fabricated by sythesysing acetylcholinesterase (ACE)-coated $\mathrm{Fe}_{3} \mathrm{O}_{4} / \mathrm{Au}$ (GMP) magnetic nanoparticulate (GMP-ACE). It is adsorbing on the surface of a SPCE modified by carbon nanotubes (CNTs)/nano- $\mathrm{ZrO}_{2} /$ prussian blue (PB)/ Nafion $(\mathrm{Nf})$ composite membrane by an external magnetic field. The biosensor could detect dimethoate from Chinese cabbage with comparable accuracy. Moreover, according to Palchetti et al. [95] such electrochemical biosensors have some advantages over other analytical transducing systems. There advantages are possibility to operate in turbid media, comparable instrumental sensitivity, and possibility of miniaturization.

Other pesticides like monocrotophos, methyl parathion and carbamyl could be detected using a sol-gel-derived silicate network containing nanoparticles. This arrangement created a biocompatible microenvironment around the enzyme molecule which aided not only in stabilizing its biological activity but also preventing its runoff from the system [96].For detection of malathion, planar gold electrode coated with chitosan hydrogel containg gold nano particles was formulated. Here thiocholine was used as an indicator and the system was based on chemisortion and desorption of the indicator with LOD of $0.03 \mathrm{ng} / \mathrm{ml}$ [97].

Though use of nanoparticles is a promising option in pesticide detection techniques more studies are essential to ensure proper standardization and increase in sensitivity.

\section{Flow Injection Analysis}

Flow injection analysis is very sensitive, rapid and efficient tool used to detect presence of pesticides in different environmental samples. Other advantages of the technique are 1) low cost of instrumentation, 2) less labor cost and smaller sample size, 3) continuous sample injection, 4) better reproducibility and 5) high sampling rate with precision. This technique involves 3 steps viz 1) sample injection, 2) sample processing and 3) detection. The sample processing can be done by dilution, solvent extraction, medium exchange, enzymatic reactions, immunoassays etc. The detection and estimation of sample makes use of mass spectrometry, spectrophotometery and measurement of fluorescence or change in $\mathrm{pH}$, use of biosensors etc [98]. Following is the brief description of various quantification methods.

\section{Use of Biosensors}

Biosensors combined with FIA are reported for detection of carbamate insecticides in water samples [99] and for carbofuran in food samples [100]. In the latter method, ACE is incorporated in lipid films supported on a methylacrylate polymer. Similar enzyme system was used in the year 2009 for detection of organophosphorous pesticides. Here ACE is immobilized by adsorption on lead oxide which acts as an electrode. It catalyzes the oxidative degradation of thiocholine in the reactor. Change in the electrochemical gradient due to oxidation of choline corresponds to the amount of pesticide present in the sample [101]. Combination of biosensors with FIA overcomes limitations of biosensors. It also offers better option for standardization and optimization.

The immobilized ACE-FIA coupled with Spectrophotometry systems were used by by Andres and Nara- yanaswamy and Xavier et al. (2000) for detection of propoxur, carbofuran and paraoxon. The detection limits were found to be $0.4 \mathrm{ng}, 3.1 \mathrm{ppb}$ and $24.7 \mathrm{ppb}$ respectively $[102,103]$.

The property of photolytic degradation of organophosphorous pesticides in presence of light has been utilized for screening the food samples for presence of organophosphorous pesticides [104]. Photolysis can be due to absorption of UV or due to oxygen and hydrogen radicals. In this method FIA is used in combination with thermal lens spectrometry [105]. Similar technique has also been employed for detection of dithiocarbamate fungicides [101] in water samples. FIA in combination with amperometry can also be used for detection of organophosphates [106].

FIA combined with immunochemilunisence assay to detect presence of atrazine in minute quantities (0.01 $\mathrm{ng} / \mathrm{ml}$ ) has been reported by Chouhan et al. (2010). The immuno-reactor consists of antibody (anti-antrazine) immobilized on protein-A sepharose matrix packed in a glass capillary column. This is then treated with atrazine and atrazine-horseradish peroxidase conjugate which facilitates competitive binding. For generation of photons the reactants are treated with hydrogen peroxide and luminal. The amount of pesticide present is inversely proportional to the number of photons generated [107,108].

Photo induced fluorosence (PIF) has been used with FIA for determination of $\alpha$-cypermethrin pesticide residues in natural water samples [108]. In nature this pesticide has low fluorescence. It can be enhanced by treatment with UV radiation and cyclodextrins. The FIA-PIF technique is rapid and can detect this pesticide in concentration range as low as $\mathrm{ng} / \mathrm{ml}$. 
FIA combined with chemiluminescence has been used for carbofuran atrazine and similar triazines detection [109-111]. The method makes use of the property of the pesticides to get converted into methylamine upon exposure to UV. The methylamine generated is made to react with tris ruthenium. The light emitted in this reaction is proportional to the amount of pesticide present [110]. Similar method has been employed for detection of the herbicide simetryn by Waseem et al. (2008). The technique is based on the oxidation of luminol by the photoproducts of the simetryn in alkaline medium [110].

Rapid quantitative analysis of pesticide residues in food and water samples is reported using FIA-MS [112]. Samples were injected directly into a triple quadrpole instrument and data was obtained at the rate of 15 s/injection with accuracy limit of $0.01 \mathrm{ng} / \mathrm{ml}$ in food samples and $0.1 \mathrm{ng} / \mathrm{ml}$ of water samples with LOD of $0.003 \mathrm{mg} / \mathrm{ml}$ for food and $0.03 \mathrm{ng} / \mathrm{ml}$ for water samples.

\section{Bioassay for Pesticide Detection}

Bioassay technique provides a rapid and sensitive assay for screening water samples for presence of herbicides. The method makes use of the property of herbicides to inhibit functioning of photo system II in Chlamydomonas reinhardtii. Briefly, C. reinhardtii grown on agar plates is incubated with samples that are dried on paper disks. The presence of herbicides is confirmed by observing the zone of inhibition around the disks. The advantage of the bioassay is that it can detect a wide range of herbicides including acifluorfen, chlorpropham, diclofopmethyl (DFM), glyphosate, isoxaben, pinnacle, trifluralin dichlorobenzonitrile (DCB), 2,4-dichlorophenoxy-acteic acid (2,4-D), metobromuron, 2-ethyl-4-chlorophenoxyacetic acid (MCPA), metribuzin, atrazine, hexazinone, norflurazon and terbacil [113]. Similar method has been described by Amutha et al. (2010) for detection of insecticides [114].

\section{Use of Capillary Electrophoresis (CE)}

Capillary electrophoresis can be employed for detection of certain pesticides [115]. The technique is useful for detection of chiral pesticides like propiconazole. This technique is a useful analytical tool for measuring the kinetics of biotransformation of stereoisomers of chiral pesticides and other pollutants from soil sediment. However the sensitivity of the method is comparatively low. Hence more studies are essential before using this method in routine practice. MS coupled with CE has high separation efficiency, low analysis time high resolution power, low consumption of samples and reagents [115].

\section{Enzyme Linked Immunosorbant Assay (ELISA)}

Use of ELISA for pesticide detection has been reported by $\mathrm{Xu} \mathrm{Zl}$ et al. (2011). The authors have employed monoclonal $\mathrm{Ab}$ based indirect ELISA technique for detection of organophosphate pesticides. This method had LOD in $\mathrm{ng} / \mathrm{ml}$. However the method has broad specificity and hence can be used only for screening of organophosphates from water samples [116].

\section{Conclusions}

The persistence of pesticides in environmental samples is a global issue. With rules and regulations of organizations like EPA, innumerable methods have been developed to detect them. Modifications in the traditional methods help in detection of specific pesticides in trace quantities. Newer methods like biosensors and nano particles, have overcome the limitations of classical methods. Use of cell based biosensors, has opened a new avenue with possibility of exploiting different microorganisms for detection purposes. Another important development is use of ELISA and monoclonal Abs for detection purpose with remarkable specificity and sensitivity. Taking this into account the authors are of the opinion that there should be 1) uniformity in permitted use of specific pesticides all over the world, 2) consensus among various organizations on MRL of these pesticides, 3) mandatory rules and regulations to abide by the established norms and most importantly 4) uniformity in the protocols for measurement of MRL in environmental samples, particularly edible products. In fact, biopesticides are the best alternative to chemical pesticides. However, government support, technology innovations, increase in social awareness and enhancement in the existing research and development are necessary to promote their use. All this will help in lowering the threats posed by the uncontrolled use of pesticides.

\section{Acknowledgements}

The authors are indebted to Dr. S. S Kadam, Vice Chancellor Bharati Vidyapeeth Deemed University (BVDU), Pune, India and Dr. G. D Sharma, Principal, Rajiv Gandhi Institute of IT and Biotechnology (BVDU) for allowing them to undertake this work.

\section{References}

[1] "International Code of Conduct on the Distribution and Use of Pesticides," Hundred and Twenty-Third Session of the FAO Council, November 2002. 
[2] B. K. Sharma, "Environmental Chemistry," Goel Publication House, New Delhi, India, 2006.

[3] "The EU Water Framework Directive-Integrated River Basin Management for Europe," European Commission Environment, 2000.

http://ec.europa.eu/environment/water/water-framework/i ndex_en.html

[4] "Pesticides," US Environmental Protection Agency, 2011. http://www.epa.gov/pesticides/

[5] "Pesticide Illnesses and Injury Surveillance," Center for Disease Control and Prevention, 2011. http://www.cdc.gov/niosh/topics/pesticides/

[6] K. G. Harley, K. Huen, R. A. Schall, N. T. Holland, A. Bradman, D. B. Barr and B. Eskenazi, "Association of Organophosphate Pesticide Exposure and Paraoxonase with Birth Outcome in Mexican-American Women," PLoS ONE, Vol. 6, No. 8, 2011.

http://www.plosone.org/article/info\%3Adoi\%2F10.1371 \%2Fjournal.pone.0023923

[7] "Potential Health Effects of Pesticide," College of Agricultural Sciences, 2011. http://pubs.cas.psu.edu/freepubs/pdfs/uo198.pdf

[8] W. J. Crinnion, “Chlorinated Pesticides: Threats to Health and Importance of Detection," Alternative Medicine Review, Vol. 14, No. 4, 2009, pp. 347-359.

[9] "Illness Associated with Exposure to Methyl BromideFumigated Produce-California, 2010," Morbidity and Mortality Weekly Report, Vol. 60, No. 27, 2011, pp. 923926.

[10] "Mercury Compounds," US Environmental Protection Agency, 2000.

http://www.epa.gov/ttn/atw/hlthef/mercury.html

[11] "Fungicides," 2011.

http://www.epa.gov/oppfead1/safety/healthcare/handbook /Chap15.pdf

[12] W. Z. Azman and W. Abdullah, "General Classification Pesticides: Rodenticides,” 2011. http://www.prn.usm.my/old_website/mainsite/bulletin/su n/1997/sun12.html

[13] J. A. Hernández, M. V-Manzanares, M. R. G.-Ortiz, B. H.-Carlos, M. P.-Torres and P. L. L.-de-Alba, "Simultaneous Spectrophotometric Determination of Atrazine and Dicamba in Water by Partial Least Squares Regression," Journal of Chilean Chemical Society, Vol. 50, No. 2, 2005, pp. 461-464.

[14] S. B. Mathew, A. K. Pillai and V. K. Gupta, "A Rapid Spectrophotometric Assay of Some Organophosphorus Pesticides in Vegetable Samples," Electronic Journal of Environmental, Agriculture and Food Chemistry, Vol. 5, No. 6, 2006, pp. 1604-1609.

[15] A. Navaratne and N. Priyantha, "Chemically Modified Electrodes for Detection of Pesticides," In: M. Stoytcheva Ed., Pesticides in the Modern World-Trends in Pesticides Analysis, 2011

http://www.intechopen.com/articles/show/title/chemically -modified-electrodes-for-detection-of-pesticides
[16] "Potentiometry and Redox Titrations," Chapter II, 2011. http://www.chem.ccu.edu.tw/ 1kc/analytical\%20chemistr y/AC1_Ch2_txt.pdf

[17] "Potentiometry," 2011. http://www.cem.msu.edu/ cem333/Week11.pdf

[18] "Conductometry," 2011. http://vedyadhara.ignou.ac.in/wiki/images/e/ed/Unit 4 C onductometric_Titrations.pdf

[19] J. Gallová, "Conductometry," 2011. http://www.fpharm.uniba.sk/fileadmin/user_upload/english /Fyzika/Determination_of_the_specific_conductance.pdf

[20] S. P. Kounaves, "Voltammetric Techniques," 2011. http://www.prenhall.com/settle/chapters/ch37.pdf

[21] "Basics of Voltametry," 2011. http://people.bath.ac.uk/chsataj/CH20016\%202006/CH20 016\%20Lecture\%2013.pdf

[22] A. J. Bard and L. R. Faulkner, "Electrochemical Methods: Fundamentals and Applications," Wiley, Hoboken, 2000.

[23] K. Wilson and J. Walker, "Priciples and Techniques of Biochemistry and Molecular Biology," Cambridge University Press, Cambridge, 2005.

[24] H. M. C. K. Kanatiwela and N. K. B. Adikaram, "A TLC-Bioassay Based Method for Detection of Fungicide Residues on Harvested Fresh Produce," Journal of the National Science Foundation of Sri Lanka, Vol. 37, No. 4, 2009, pp. 257-262.

[25] S. Butz and H. J. Stan, "Screening of 265 Pesticides in Water by Thin-Layer Chromatography with Automated Multiple Development," Analytical Chemistry, Vol. 67, No. 3, 1998, pp. 620-630.

[26] T. Tuzimski, "Determination of Pesticides in Water Samples from the Wieprz-Krzna Canal in the LeczyńskoWłodawskie Lake District of Southeastern Poland by Thin-Layer Chromatography with Diode Array Scanning and High-Performance Column Liquid Chromatography with Diode Array Detection," Journal of AOAC International, Vol. 91, No. 5, 2009, pp. 1203-1209.

[27] J. P. Lautié, V. Stankovic and G. Sinoquet, "Determination of Chlormequat in Pears by High-Performance Thin Layer Chromatography and High-Performance Liqui Chromatography with Conductimetric Detection," Analusis, Vol. 28, No. 2, 2000, pp. 155-158. doi:10.1051/analusis:2000109

[28] R. Akkad, "Determination of Organophosphorus and Carbamate Insecticides in Food Samples by High-Performance Thin-Layer Chromatography Multi-Enzyme Inhibition Assay," PhD Dissertation, Institute of Food Chemistry, University of Hohenheim, Stuttgart, Germany, 2011.

[29] Joseph Sharma, "Recent Advances in Thin-Layer Chromatography of Pesticides," Journal of AOAC International, Vol. 84, No. 4, 2001, pp. 993-1000.

[30] W. M. Niessen, P. Manini and R. Andreoli, "Matrix Effects in Quantitative Pesticide Analysis Using Liquid Chromatography-Mass Spectrometry," Mass Spectrometry Reviews, Vol. 25, No. 6, 2006, pp. 881-899. doi:10.1002/mas.20097 
[31] S.-H. TSeng, Y.-J. Lin, H.-F. Lee, S.-C. Su, S.-S. Chou and D.-F. Hwang, "A Multiresidue Method for Determining 136 Pesticides and Metabolites in Fruits and Vegetables: Application of Macroporous Diatomaceous Earth Column," Journal of Food and Drug Analysis, Vol. 15, No. 3, 2007, pp. 316-324.

[32] P. L. Wylie, "Trace Level Pesticide Analysis by GC/MS Using Large-Volume Injection," 2011. http://cp.chem.agilent.com/Library/applications/5966121 4.pdf

[33] H. A. Moye, "Improved Microwave Emission Gas Chromatography Detector for Pesticide Residue Analysis," 2011. http://pubs.acs.org/doi/abs/10.1021/ac60256a007

[34] L. V. Podhorniak, J. F. Negron and F. D. Griffith Jr., "Gas Chromatography with Pulsed Flame Photometric Detection Multiresidue Method for Organophosphate Pesticide and Metabolite Residues at the Parts-Per-Billion Level in Representatives Commodities of Fruits and Vegetable Crop Groups," Journal of AOAC International, Vol. 84, No. 3, 2001, pp. 873-890.

[35] S. Johnson, N. Saikia and A. Kumar, "Analysis of Pesticide Residues in Soft Drinks," CSE Report, August, 2006. http://www.indiaenvironmentalportal.org.in/files/labrepor $\mathrm{t} / \mathrm{pdf}$

[36] B. Du, H. Liu, et al., "Determination of Organochlorine Pesticide Residues in Herbs by Capillary Electrophoresis," Life Science Journal, Vol. 4, No.1, 2007, pp. 40-42.

[37] D. Bielawski, E. Ostrea Jr., N. Posecion Jr., M. Corrion and J. Seagraves, "Detection of Several Classes of Pesticides and Metabolites in Meconium by Gas Chromatography-Mass Spectrometry," Chromatographia, Vol. 62, No. 11-12, 2005, pp. 623-629. doi:10.1365/s10337-005-0668-7

[38] L. Alder, K. Greulich, G. Kempe and B. Vieth, "Residue Analysis of 500 High Priority Pesticides: Better by GCMS or LC-MS/MS," Mass Spectrometry Reviews, Vol. 25, No. 6, 2006, pp. 838-865. doi:10.1002/mas.20091

[39] L. Vodeb and B. Petanovska-Ilievska, "HPLC-DAD with Different Types of Column for Determination of $\beta$-Cyfluthrin in Pesticide," Acta Chromatographica, Vol. 17, 2006, pp. 188-201.

[40] P. Vinas, N. Campillo, I. Lopez-Garcia, N. Aguinaga and M. Hernandez-Cordoba, "Capillary Gas Chromatography with Atomic Emission Detection for Pesticide Analysis in Soil Samples," Journal of Agricultural and Food Chemistry, Vol. 51, No. 3, 2003, pp. 3704-3708. doi:10.1021/jf021106b

[41] S. Islam, M. S. Hossain, N. Nahar, M. Mosihuzzaman and M. I. R. Mamun, "Application of High Performance Liquid Chromatography to the Analysis of Pesticide Residues in Eggplants," Journal of Applied Sciences, Vol. 9, No. 5, 2009, pp. 973-977. doi:10.3923/jas.2009.973.977

[42] D. R. Thevenot, K. Toth, R. A. Durst and G. S. Wilson, "Electrochemical Biosensors: Recommended Definitions and Classification," Biosensors and Bioelectronics, Vol. 16, No. 1-2, 2001, pp. 121-131.

[43] A. Hildebrandt, R. Bragos, S. Lacorte and J. L.Marty, "Performance of a Portable Biosensor for the Analysis of
Organophosphorus and Carbamate Insecticides in Water and Food," Sensors and Actuators B: Chemical, Vol. 133, No. 1, 2008, pp. 195-201. doi:10.1016/j.snb.2008.02.017

[44] J. Tschmelak, G. Proll, J. Riedt, J. Kaiser, P. Kraemmer, L. Barzaga, J. S. Wilkinson, P. Hua, J. P. Hole, R. Nudd, M. Jackson, R. Abuknesha, D. Barcelo, S. RodriguezMozaz, M. J. Lopez de Alda, F. Sacher, J. Stien, J. Slobodnik, P. Oswald, H. Kozmenko, E. Korenkova, L. Tothova, Z. Krascsenits and G. Gauglitz, "Automated Water Analyser Computer Supported System (AWACSS) Part II: Intelligent, Remote-Controlled, Cost-Effective, On-line, Water Monitoring Measurement System," Biosensors and Bioelectronics, Vol. 20, No. 8, 2005, pp. 1509-1519. doi:10.1016/j.bios.2004.07.033

[45] H. Alain, R. Jordi, B. Ramon, T. Marius and L. Silvia, "Development of a Portable Biosensor for Screening Neurotoxic Agents in Water Samples," Talanta, Vol. 75, No. 5, pp. 1208-1213.

[46] B. B. Dzantiev, E. V. Yazynina, A. V. Zherdev, Y. V. Plekhanova, A. N. Reshetilov, S. C. Chang and C. J. McNeil, "Determination of the Herbicide Chlorsulfuron by Amperometric Sensor Based on Separation-Free Bienzyme Immunoassay," Sensors and Actuators B: Chemical, Vol. 98, No. 2-3, 2004, pp. 254-261. doi:10.1016/j.snb.2003.10.021

[47] I. Palchetti, A. Cagnini, M. Del Carlo, C. Coppi, M. Mascini and A. P. F. Turner, "Determination of Acetylcholinesterase Pesticides in Real Samples Using a Disposable Biosensor," Analytica Chimica Acta, Vol. 337, No. 3, 1997, pp. 315-321. doi:10.1016/S0003-2670(96)00418-7

[48] T. T. Bachmann, B. Leca, F. Villatte, J. L. Marty, D. Fournier and R. D. Schmid, "Improved Multianalyte Detection of Organophosphate and Carbamate with Disposable Multielectrode Biosensors Using Recombinant $\mathrm{Mu}-$ tants of Drosophila Acetylcholinesterase and Artificial neutral Network," Biosensors and Bioelectronics, Vol. 15, No. 3-4, 2000, pp. 193-201. doi:10.1016/S0956-5663(00)00055-5

[49] T. Montesinos, S. Perez-Munguia, F. Valdez and J. L. Marty, "Disposable Cholinesterase Biosensor for the Detection of Pesticides in Water-Miscible Organic Solvents," Analytica Chimica Acta, Vol. 431, No. 2, 2001, pp. 231-237. doi:10.1016/S0003-2670(00)01235-6

[50] K. A. Joshi, J. Tang, R. Haddon, J. Wang, W. Chen and A. Mulchaldani, "A Disposable Biosensors for Organophosphorus Nerve Agents Based on Carbon Nanotubes Modified Thick Film Strip Electrodes," Electroanalysis, Vol. 17, No. 1, 2005, pp. 54-58. doi:10.1002/elan.200403118

[51] B. Prieto-Simón, M. Campàs, S. Andreescu and J.-L. Marty, "Trends in Flow-Based Biosensing Systems for Pesticide Assessment," Sensors, Vol. 6, No. 10, 2006, pp. 1161-1186. doi:10.3390/s6101161

[52] C. Tran-Minh, "Biosensors in Flow-Injection Systems for Biomedical Analysis, Process and Environmental Monitoring," Journal of Molecular Recognition, Vol. 9, No. 5-6, 1996, pp. 658-663. doi:10.1002/(SICI)1099-1352(199634/12)9:5/6<658::AI 


\section{D-JMR317>3.0.CO;2-M}

[53] M. P. Marco, S. Gee and B. D. Hammock, "Immunochemical Techniques for Environmental Analysis I: Immunosensors," TrAC Trends in Analytical Chemistry, Vol. 14, No. 7, 1995, pp. 341-350. doi:10.1016/0165-9936(95)97062-6

[54] B. Hock, A. Dankwardt, K. Kramer and A. Marx, "Immunochemical Techniques: Antibody Production for Pesticide Analysis," Analytica Chimica Acta, Vol. 311, No. 3, 1995, pp. 393-405. doi:10.1016/0003-2670(95)00148-S

[55] M. A. González-Martínez, J. Penalva, R. Puchades, A. Maquieira, B. Ballesteros, M. P. Marco and D. Barceló, "An Immunosensor for the Automatic Determination of the Antifouling Agent Irgarol 1051 in Natural Waters," Environmental Science \& Technology, Vol. 32, No. 21, 1998, pp. 3442-3447. doi:10.1021/es980120v

[56] E. Mallat, C. Barzen, A. Klotz, A. Brecht, G. Gauglitz and D. Barceló, "River Analyzer for Chlorotriazines with a Direct Optical Immunosensor," Environmental Science \& Technology, Vol. 33, No. 6, 1999, pp. 965-971. doi:10.1021/es980866t

[57] M. A. González-Martínez, S. Morais, R. Puchades, A. Maquieira, A. Abad and A. Montoya, "Monoclonal Antibody-Based Flow-Through Immunosensor for Analysis of Carbaryl," Analytical Chemistry, Vol. 69, No. 14, 1997, pp. 2812-2818. doi:10.1021/ac961068t

[58] C. G. Bauer, A. V. Eremenko, E. Ehrentreich-Fŏrster, F. F. Bier, A. Makower, H. B. Halsall, W. R. Heineman and F. W. Scheller, "Zeptomole-Detecting Biosensor for Alkaline Phosphatase in an Electrochemical Immunoassay for 2,4-Dichlorophenoxyacetic Acid," Analytical Chemistry, Vol. 68, No. 15, 1996, pp. 2453-2458. doi:10.1021/ac960218x

[59] R. T. Andres and R. Narayanaswamy, "Fibre-Optic Pesticide Biosensor Based on Covalently Immobilized Acetylcholinesterase and Thymol Blue," Talanta, Vol. 44, No. 8, 1997, pp. $1335-1352$. doi:10.1016/S0039-9140(96)02071-1

[60] R.-A Doong, H.-M. Shih and S.-H. Lee, "Sol-Gel-Derived Array DNA Biosensor for the Detection of Polycyclic Aromatic Hydrocarbons in Water and Biological Samples," Sensors and Actuators B, Vol. 111-112, No. 110, 2005, pp. 323-330.

[61] H.-S. Lee, Y. A. Kim, Y. A. Cho and Y. T. Lee, "Oxidation of Organophosphorus Pesticides for the Sensitive Detection by a Cholinesterase-based Biosensor," Chemosphere, Vol. 46, No. 4, 2002, pp. 571-576. doi:10.1016/S0045-6535(01)00005-4

[62] J. S. Van Dyk and B. Pletschke, "Review on the Use of Enzymes for the Detection of Organochlorine, Organophosphate and Carbamate Pesticides in the Environment," Vol. 82, No. 3, 2011, pp. 291-307.

[63] J. P. Sherry, "Environmental Chemistry: The Immunoassay Option," Critical Reviews in Analytical Chemistry, Vol. 23, No. 4, 1992, pp. 217-300. doi:10.1080/10408349208050856

[64] E. P. Meulenberg, W. H. Mulder and P. G. Stoks, "Im- munoassays for Pesticides," Environmental Science Technolology, Vol. 29, No. 3, 1995, pp. 553-561. doi: $10.1021 / \mathrm{es} 00003 \mathrm{a} 001$

[65] O. A. Sadik and J. M. Van Emon, "Application of Electrochemical Immunosensors to Environmental Monitoring," Biosensors and Bioelectronics, Vol. 11, No. 8, 1996, pp. 1-11. doi:10.1016/0956-5663(96)85936-7

[66] A. Mulchandani, P. Mulchandani, S. Chauhan, I. Kaneva and W. Chen, "A Potentiometric Microbial Biosensor for Direct Determination of Organophosphate Nerve Agents," Electroanalysis, Vol. 10, No. 11, 1998, pp. 733-737. doi:10.1002/(SICI)1521-4109(199809)10:11<733::AID-E LAN733>3.0.CO;2-X

[67] Y. Lei, P. Mulchandani, J. Wang, W. Chen, W. Chen and A. Mulchandani, "Highly Sensitive and Selective Amperometric Microbial Biosensor for Direct Determination of $p$-Nitrophenyl-Substituted Organophosphate Nerve Agents," Environmental Science \& Technology, Vol. 39, No. 22, 2005, pp. 8853-8857. doi:10.1021/es050720b

[68] M. Priti, C. Wilfred and M. Ashok, "Microbial Biosensor for Direct Determination of Nitrophenyl-Substituted Organophosphate Nerve Agents Using Genetically Modified Moraxella sp.," Analytica Chimica Acta, Vol. 568, No. 1-2, 2006, pp. 217-221. doi:10.1016/j.aca.2005.11.063

[69] C. Chouteau, S. Dzyadevych, C. Durrieu and J. M. Chovelon, "A Bienzymatic Whole Cell Conductometric Biosensor for Heavy Metal Ions and Pesticides Detection in Water Samples," Biosensors and Bioelectronics, Vol. 21, No. 2, 2005, pp. 273-281. doi:10.1016/j.bios.2004.09.032

[70] A. L. Simonian, J. K. Grimsley, A. W. Flounders, J. S. Schoeniger, T. C. Cheng, J. J. DeFrank and J. R. Wild, "Enzyme-Based Biosensor for the Direct Detection of Fluorine-Containing Organophosphates," Analytica Chimica Acta, Vol. 442, No. 1, 2001, pp. 15-23. doi:10.1016/S0003-2670(01)01131-X

[71] P. Mulchandani, W. Chen and A. Mulchandani, "FlowInjection Amperometric Enzyme Biosensor for Direct Determination of Organophosphate Nerve Agents," Environmental Science \& Technology, Vol. 35, No. 12, 2001, pp. 2562-2565. doi:10.1021/es001773q

[72] M. J. Schoening, R. Krause, K. Block, M. Musahmen, A. Mulchandani and J. Wang, "A Dual Amperometric/Potentiometric FIA-Based Biosensor for the Distinctive Detection of Organophosphorus Pesticides," Sensors and Actuators B: Chemical, Vol. 95, No. 1-3, 2003, pp. 291- 296. doi:10.1016/S0925-4005(03)00426-X

[73] J. Wang, R. Krause, K. Block, M. Musameh, A. Mulchandani, P. Mulchandani, W. Chen and M. J. Schoening, "Dual Amperometric Potentiometric Biosensor Detection System for Monitoring Organophosphorus Neurotoxins," Analytica Chimica Acta, Vol. 469, No. 2, 2002, pp. 197203. doi:10.1016/S0003-2670(02)00666-9

[74] K. Reybier, S. Zairi and N. Jaffrezic-Renault, "The Use of Polyethylenimine for Fabrication of Potentiometric Cholinesterase Biosensors," Talanta, Vol. 56, No. 6, pp. 1015-1020. doi:10.1016/S0039-9140(01)00588-4

[75] D. Du, X. Huang, J. Cai and A.-D. Zhang, "Amperomet- 
ric Detection of Triazophos Pesticide Using Acetylcholinesterase Biosensor Based on Multiwall Carbon Nanotube-Chitosan Matrix," Sensors and Actuators B: Chemical, Vol. 127, No. 2, pp. 531-535.

[76] E. V. Gogol, G. A. Evtugyn, J. L. Marty, H. C. Budnikov and V. G. Winter, "Amperometric Biosensors Based on Nafion-Coated Screenprinted Electrodes for the Determination of Cholinesterase Inhibitors," Talanta, Vol. 53, No. 2, pp. 379-389. doi:10.1016/S0039-9140(00)00507-5

[77] T. T. Bachmann, B. Leca, F. Villatte, J.-L.Marty, D. Fournier and R. D. Schmid, "Improved Multianalyte Detection of Organophosphate and Carbamate with Disposable Multielectrode Biosensors Using Recombinant Mutants of Drosophila Acetylcholinesterase and Artificial Neutral Network," Biosensors and Bioelectronics, Vol. 15, No. 3-4, pp. 193-201. doi:10.1016/S0956-5663(00)00055-5

[78] F. Mazzei, F. Botre and C. Botre, "Acid Phosphatase/Glucose Oxidase Based Biosensors for the Determination of Pesticide," Analytica Chimica Acta, Vol. 336, No. 1-3, 1996, pp. 67-75. doi:10.1016/S0003-2670(96)00378-9

[79] K. Rekha, M. D. Gouda, M. S. Thakur and N. G. Karanth, "Ascorbate Oxidase Based Amperometric Biosensor for Organophosphorus Pesticide Monitoring," Biosensors and Bioelectronics, Vol. 15, No. 9-10, 2000, pp. 499-502. doi:10.1016/S0956-5663(00)00077-4

[80] Y. D. De Albuquerque and L. F. Ferreira, "Amperometric Biosensing of Carbamate and Organophosphate Pesticides Utilizing Screenprinted Tyrosinase-Modified Electrodes," Analytica Chimica Acta, Vol. 596, No. 2, 2007, pp. 210-221. doi:10.1016/j.aca.2007.06.013

[81] M. T. Perez-Pita, A. J. Reviejo, F. J. Manuel-de-Villena and J. M. Pingarron, "Amperometric Selective Biosensing of Dimethyl- and Diethyldithiocarbamates Based on Inhibition Processes in a Medium of Reversed Micelles," Analytica Chimica Acta, Vol. 340, No. 1-3, 1997, pp. 89-97. doi:10.1016/S0003-2670(96)00552-1

[82] A. Seki, F. Ortega and J. L. Marty, "Enzyme Sensor for the Detection of Herbicides Inhibiting Acetolactate Synthase," Analytical Letters, Vol. 29, No. 8, 1996, pp. 12591271. doi:10.1080/00032719608001479

[83] T. Noguer and J. L. Marty, "High Sensitive Bienzymic Sensor for the Detection of Dithiocarbamate Fungicides," Analytica Chimica Acta, Vol. 347, No. 1-2, 1997, pp. 6370. doi:10.1016/S0003-2670(97)00127-X

[84] J. Halamek, M. Hepel and P. Skladal, "Investigation of Highly Sensitive Piezoelectric Immunosensors for 2,4-Dichlorophenoxyacetic Acid," Biosensors and Bioelectronics, Vol. 16, No. 4-5, 2001, pp. 253-260. doi:10.1016/S0956-5663(01)00132-4

[85] J. Pribyl, M. Hepel, J. Halámek and P. Skladal, "Development of Piezoelectric Immunosensors for Competitive and Direct Determination of Atrazine," Sensors and Actuators B: Chemical, Vol. 91, No. 1-3, 2003, pp.333-341. doi:10.1016/S0925-4005(03)00107-2

[86] J. Halamek, J. Pribyl, A. Makower, P. Skladal and F. W.
Scheller, "Sensitive Detection of Organophosphates in River Water by Means of a Piezoelectric Biosensor," Analytical and Bioanalytical Chemistry, Vol. 382, No. 8, 2005, pp.1904-1911. doi:10.1007/s00216-005-3260-y

[87] G. G. Guilbault, B. Hock and R. Schmid, "A Piezoelectric Immunosensor for Atrazine in Drinking Water," Biosensors and Bioelectronics, Vol. 7, No. 6, 1992, pp. 411419. doi:10.1016/0956-5663(92)85040-H

[88] D. Erickson, S. Mandal, H. Allen, J. Yang and B. Cordovez, "Nanobiosensors: Optofluidic, Electrical and Mechanical Approaches to Biomolecular Detection at the Nanoscale," Microfluid Nanofluidics, Vol. 4, No. 1-2, 2008, pp. 33-52. doi:10.1007/s10404-007-0198-8

[89] J. Wang, G. Rivas, E. Cai, P. Palecek, H. Nielsen, N. Shiraishi, D. Dontha, C. Luo, M. Parrado, P. A. M. Chicarro, F. S. Farias, D. H. Valera, M. Grant, M. Ozsoz and M. N. Flair, "DNA Electrochemical Biosensors for Environmental Monitoring. A Review," Analytica Chimica Acta, Vol. 347, No. 1-2, 1997, pp.1-8. doi:10.1016/S0003-2670(96)00598-3

[90] P. G. He, Y. Xu and Y. Z. Fang, "A Review: Electrochemical DNA Biosensors for Sequence Recognition," Analytical Letters, Vol. 38, No. 15, 2005, pp. 2597-2623. doi:10.1080/00032710500369794

[91] Krystyna Pyrzynska, "Carbon Nanotubes as Sorbents in the Analysis of Pesticides," Chemosphere, Vol. 83, No. 11, 2011, pp.1407-1413. doi:10.1016/j.chemosphere.2011.01.057

[92] S. Olga and R. K. Jon, "An Acetylcholinesterase Enzyme Electrode Stabilized by an Electrodeposited Gold Nanoparticle Layer," Electrochemistry Communications, Vol. 9, No. 5, 2007, pp. 935-940. doi:10.1016/i.elecom.2006.11.021

[93] M. Alvarez, A. Calle, J. Tamayo, J. L. M. Lechuga, A. Abad and A. Montoya, "Development of Nanomechanical Biosensors for Detection of the Pesticide DDT," Biosensor Bioelectronics, Vol. 18, No. 5-6, 2003, pp. 649653. doi:10.1016/S0956-5663(03)00035-6

[94] N. Gan, X. Yang, D. Xie, Y. Wu and W. Wen, "A Disposable Organophosphorus Pesticides Enzyme Biosensor Based on Magnetic Composite Nano-Particles Modified Screen Printed Carbon Electrode," Sensors, Vol. 10, No. 1, 2010, pp. 625-638. doi:10.3390/s100100625

[95] I. Palchetti, S. Laschi and M. Mascini, "Electrochemical Biosensor Technology: Application to Pesticide Detection," Electrochemical and Mechanical Detectors, lateral Flow and Ligands for Biosensors, Human Press, Springer, LLC, USA, 2009, p. 115.

[96] D. Du, S.-Z. Chen, J. Cai and A.-D. Zhang, "Electrochemical Pesticide Sensitivity Test Using Acetylcholinesterase Biosensor Based on Colloidal Gold Nanoparticle Modified Sol-Gel Interface," Talanta, Vol. 74, No. 4, 2008, pp. 766-772.

[97] D. Du, J.-W. Ding, Y. Tao and X. Chen, "Application of Chemisorption/Desorption Process of Thiocholine for Pesticide Detection Based on Acetylcholinesterase Biosensor," Sensors and Actuators B: Chemical, Vol. 134, No. 2, 
2008, pp. 908-912.

[98] A. Parikh, K. Patel, C. Patel and B. N. Patel, "Flow Injection: A New Approach in Analysis," Journal of Chemical and Pharmaceutical Research, Vol. 2, No. 2, 2010, pp. 118-125.

[99] S. Suwansa-ard, P. Kanatharana, P. Asawatreratanakul, C. Limsakul, B. Wongkittisuksa and P. Thavarungkul, "Semi Disposable Reactor Biosensors for Detecting Carbamate Pesticides in Water," 2005.

http://www.sciencedirect.com/science/article/pii/S095656 6304005512

[100] D. P. Nikolelis, M. G. Simantiraki, C. G. Siontorou and K. Toth, "Flow Injection Analysis of Carbofuran in Foods Using Air Stable Lipid Film Based Acetylcholinesterase Biosensor," Analytica Chimica Acta, Vol. 537, No. 1-2, 2005, pp. 169-177.

[101] Y.-Y. Wei, Y. Li, Y.-H. Qu, F. Xiao, G.-Y. Shi and L.-T. Jin, "A Novel Biosensor Based on Photoelectro-Synergistic Catalysis for Flow-Injection Analysis System/Amperometric Detection of Organophosphorous Pesticides," Analytica Chimica Acta, Vol. 643, No. 1-2, 2009, pp. 13-18. doi:10.1016/j.aca.2009.03.045

[102] M. P. Xavier, B. Vallejo, M. D. Marazuela, M. C. Moreno-Bondi, F. Baldini and A. Falai, "Fiber Optic Monitoring of Carbamate Pesticides Using Porous Glass with Covalently Bound Chlorophenolred," Biosensors and Bioelectronics, Vol. 14, No. 12, 2000, pp. 895-905. doi:10.1016/S0956-5663(99)00066-4

[103] M. Franko, M. Sarakha, A. Cibej, A. Boskin, M. Bavcon and P. Trebse, "Photodegradation of Pesticides and Application of Bioanalytical Methods for Their Detection," Pure and Applied Chemistry, Vol. 77, No. 10, 2005, pp. 1727-1736. doi: $10.1351 /$ pac200577101727

[104] R. S. Chouhan, K. V. Rana, C. R. Suri, R. K. Thampi and M. S. Thakur, "Trace-Level Detection of Atrazine Using Immuno-Chemiluminescence: Dipstick and Automated Flow Injection Analyses Formats," Journal of AOAC International, Vol. 93, No. 1, 2010, pp. 28-35.

[105] A. Waseem, M. Yaqoob and A. Nabi, "Photodegradation and Flow-Injection Determination of Dithiocarbamate Fungicides in Natural Water with Chemiluminescence Detection," Analytical Sciences, Vol. 25, No, 3, 2009, pp. 395-400. doi:10.2116/analsci.25.395

[106] H.-Y. Hu, X.-Y. Liu, F. Jiang, X. Yao and X.-C. Cui, “A Novel Chemiluminescence Assay of Organophosphorous Pesticide Quinalphos Residue in Vegetable with Luminol Detection," Chemistry Central Journal, Vol. 4, No. 13, 2010, p. 13.

[107] L. Pogacknic and M. Franko, "Photothermal Bioanalyti- cal Methods for Pesticide Toxicity Testing," Arhiv Za Higijenu Rada I Toksikologiju, Vol. 54, No. 3, 2003, pp. 197-205.

[108] J.-J. Aaron, M. Mbaye and M. D. G. Seye, "Determination of A-Cypermethrin Insecticide Residues in Senegal Waters by a Flow Injection Analysis-Photochemically Induced Fluorescence (FIA-PIF) Method," 2011. $\mathrm{http} / / /$ balwois.com/balwois/administration/full paper/ffp1422.pdf

[109] T. Pérez-Ruiz, C. Martínez-Lozano, V. Tomás and J. Martín, "Chemiluminescence Determination of Carbofuran and Promecarb by Flow Injection Analysis Using Two Photochemical Reactions," Analyst, Vol. 127, No. 11, 2002, pp. 1526-1530. doi:10.1039/b207460p

[110] A. Waseem, M. Yaqoob and A. Nabi, "Photodegradation and Flow-Injection Determination of Simetryn Herbicide by Luminol Chemiluminescence Detection," Analytical Sciences, Vol. 24, No. 8, 2008, pp. 979-983. doi:10.2116/analsci.24.979

[111] D. J. Beale, N. A. Porter and F. A. Roddick, "A Fast Screening Method for the Presence of Atrazine and Other Triazines in Water Using Flow Injection with Chemiluminescent Detection," Talanta, Vol. 78, No. 2, 2009, pp. 342-347.

[112] S. C. Nanita, A. M. Pentz and F. Q. Bramble, "HighThroughput Pesticide Residue Quantitative Analysis Achieved by Tandem Mass Spectrometry with Automated Flow Injection," Analytical Chemistry, Vol. 81, No. 8, 2009, pp. 3134-3142. doi:10.1021/ac900226w

[113] X.-Q. Li, A. Ng, R. King and D. G. Durnford, "A Rapid and Simple Bioassay Method for Herbicide Detection," Biomarker Insights, Vol. 3, 2008, pp. 287-291.

[114] M. Amutha, J. G. Banu, T. Surulivelu and N. Gopalakrishnan, "Effect of Commonly Used Insecticides on the Growth of White Muscardine Fungus, Beauveria bassiana under Laboratory Conditions," Journal of Biopesticides, Vol. 3, No. 1, 2010, pp. 143-146.

[115] A. W. Garrison, J. K. Avants and R. D. Miller, "Loss of Propiconazole and Its Four Stereoisomers from the Water Phase of Two Soil-Water Slurries as Measured by Capillary Electrophoresis," 2011. http://www.mdpi.com/16604601/8/8/3453/

[116] Z. L. Xu, D. P. Zeng, J. Y. Yang, Y. D. Shen, R. C. Beier, H. T. Lei, H. Wang and Y. M. Sun, "Monoclonal Antibody-Based Broad-Specificity Immunoassay for Monitoring Organophosphorus Pesticides in Environmental Water Samples," Journal of Environmental Monitoring, Vol. 13, No. 11, 2011, pp. 3040-3048. 